\title{
ADSORPSI ION LOGAM TEMBAGA(II) DALAM AIR DENGAN SERBUK TULANG IKAN GURAME (Osphronemus gourami Lac)
}

\author{
Riska FARAh Diba ${ }^{1}$, Vina Amalia ${ }^{1 *}$, Eko Prabowo Hadisantoso ${ }^{1}$, DAN YusuF Rohmatulloh ${ }^{1}$ \\ ${ }^{1}$ Jurusan Kimia, Fakultas Sains dan Teknologi, UIN Sunan Gunung Djati Bandung, \\ Jl. A.H. Nasution No. 105, Bandung
}

*Email korespondensi: vinaamalia@uinsgd.ac.id

\begin{tabular}{|c|c|}
\hline Informasi Artikel & Abstrak/Abstract \\
\hline $\begin{array}{l}\text { Riwayat Naskah: } \\
\text { Diterima pada } 26 \\
\text { November } 2017 \\
\text { Diterima setelah } \\
\text { direvisi pada } 28 \\
\text { Desember } 2017 \\
\text { Diterbitkan pada } 29 \\
\text { Desember } 2017 \\
\text { Kata Kunci: } \\
\text { adsorpsi; } \\
\text { hidroksiapatit; tulang } \\
\text { ikan Gurame; logam } \\
\text { Cu(II). }\end{array}$ & $\begin{array}{l}\text { Tulang ikan Gurame dapat dimanfaatkan sebagai material penyerap (adsorben) karena } \\
\text { memiliki kadar kalsium fosfat yang tinggi yaitu sebesar } 65 \% \text {. kalsium hidroksiapatit } \\
\left(\mathrm{Ca}_{10}\left(\mathrm{PO}_{4}\right)_{6} \mathrm{OH}_{2}\right) \text { dapat dimanfaatkan sebagai adsorben karena kalsium hidroksiapatit } \\
\text { merupakan biokeramik yang dapat mengadsorpsi logam dengan cara pertukaran ion. Pada } \\
\text { penelitian ini ion logam } \mathrm{Cu}(\mathrm{II}) \text { dipilih sebagai adsorbat karena } \mathrm{Cu}(\mathrm{II}) \text { merupakan salah satu } \\
\text { pencemar badan air yang berbahaya bagi tubuh. Adsorben tulang ikan Gurame dikarakterisasi } \\
\text { dengan XRD, XRF, } \mathrm{SEM} \text {, dan FTIR sehingga diketahui struktur adsorben yang terbentuk } \\
\text { adalah hidroksiapatit }\left(\mathrm{Ca}_{10}\left(\mathrm{PO}_{4}\right)_{6} \mathrm{OH}_{2}\right) \text { dengan kristalinitas rendah dengan nilai rasio mol } \mathrm{Ca} / \mathrm{P} \\
\text { sebesar } 1,97 \text { karena dominan kalsium pada adsorben. Agar didapatkan kondisi adsorpsi } \\
\text { optimum dilakukan optimasi terhadap konsentrasi larutan } \mathrm{Cu}(\mathrm{II}) \text {, pH, waktu kontak dan massa } \\
\text { adsorben. Hasil optimasi didapatkan konsentrasi larutan } \mathrm{Cu}(\mathrm{II}) \text { optimum adalah } 40 \text { mg/L } \\
\text { dengan pH } 4 \text {, waktu kontak } 45 \text { menit dan massa adsorben } 1,0 \text { gram. Dari hasil penelitian } \\
\text { disimpulkan tulang ikan Gurame dapat dimanfaatkan sebagai adsorben logam } \mathrm{Cu}(\mathrm{II}) \text { karena } \\
\text { memiliki efisiensi adsorpsi sebesar } 89,5 \% \text { dan kapasitas adsorpsi sebesar } 7,1604 \mathrm{mg} / \mathrm{g} \text {. }\end{array}$ \\
\hline $\begin{array}{l}\text { Keywords: } \\
\text { adsorption; } \\
\text { hydroxyapatite; } \\
\text { gouramy's bone; } \\
\text { Cu(II) metal. }\end{array}$ & 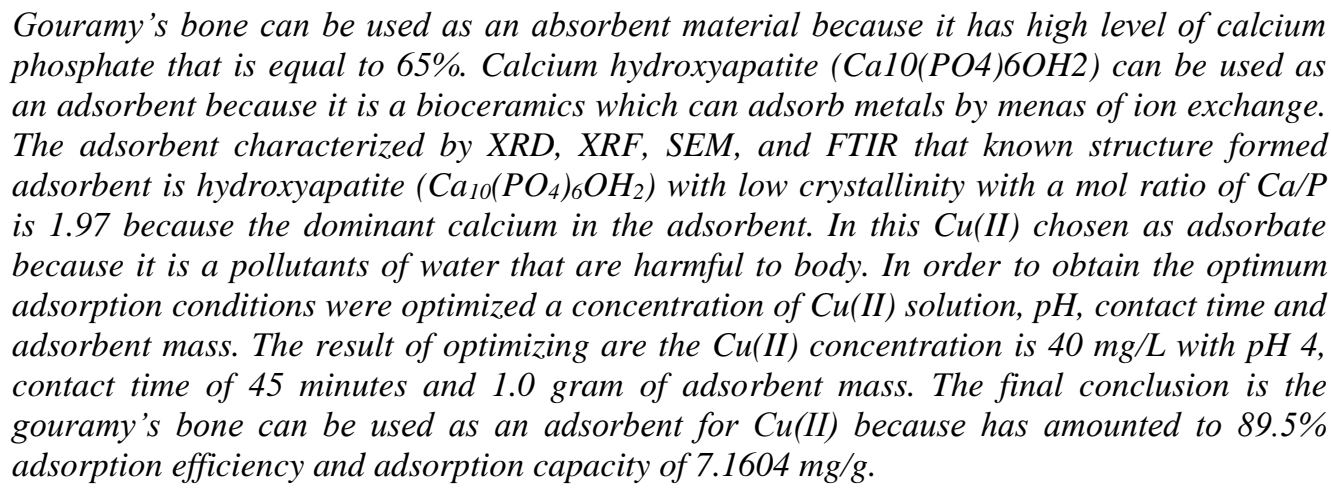 \\
\hline
\end{tabular}

\section{PENDAHULUAN}

Perkembangan industri pada saat ini telah mengalami kemajuan yang sangat pesat. Seiring kemajuan tersebut dihasilkan pula limbah gas, padat dan cair yang berkontribusi terhadap kerusakan lingkungan. Logam berat yang terkandung dalam limbah cair dapat mencemari badan air di sekeliling wilayah industri dan akan meracuni makhluk hidup yang hidup di perairan tersebut. Saat ini kontaminasi logam berat pada suatu perairan sudah menjadi hal yang tidak asing lagi mengingat banyaknya industri yang membuang limbah cairnya ke badan air. Data hasil analisis kadar logam berat pada salah satu waduk di Jawa Barat menunjukkan konsentrasi logam $\mathrm{Hg}, \mathrm{Pb}, \mathrm{Cd}$, dan $\mathrm{Cu}$ yang telah melewati ambang batas maksimum yaitu berturutturut 2,00;30,00; 10,00, dan 20,00 mg/L [1].
Untuk mengurangi kadar logam berat yang dihasilkan dari suatu industri maka perlu dilakukan penanganan terhadap limbah cair yang akan dibuang, baik itu penanganan secara fisik, biologi ataupun secara kimia. Salah satu metode yang ekonomis dan memiliki efisiensi tinggi adalah metode adsorpsi [2].

Tulang binatang dapat dimanfaatkan sebagai adsorben untuk menghilangkan logam berat dari perairan. Tulang terdiri dari $70 \%$ senyawa anorganik dan $30 \%$ senyawa organik. Kalsium hidroksiapatit $\mathrm{Ca}_{10}\left(\mathrm{PO}_{4}\right)_{6}(\mathrm{OH})_{2}$ [HAP] merupakan komponen senyawa anorganik penyusun utama tulang yang dapat dijadikan adsorben melalui reaksi pertukaran ion [3]. Salah satu tulang binatang yang mudah ditemukan adalah tulang ikan Gurame. Potensi tulang ikan Gurame untuk dijadikan adsorben logam $\mathrm{Cu}$ sangat besar. Pemanfaatan tulang ikan Gurame sebagai adsorben bersifat lebih ekonomis dari 
pada metode sebelumnya karena adsorben tulang ikan Gurame dapat dibuat dengan mudah yaitu dengan aktivator $\mathrm{NaOH}$.

Pada penelitian ini dilakukan analisis kemampuan serbuk tulang ikan Gurame untuk mengadsorpsi logam $\mathrm{Cu}$ dalam air dengan metode batch. Selain itu beberapa optimasi dilakukan agar didapatkan kondisi penyerapan yang optimum. Hasil penelitian ini dapat menjadi solusi untuk pengolahan air buangan dari industri yang mengandung logam berat $\mathrm{Cu}$.

\section{EKSPERIMEN}

\section{Material}

Bahan-bahan yang digunakan dalam penelitian ini adalah sampel tulang ikan Gurame, $\mathrm{NaOH}, \mathrm{CuSO}_{4}, \mathrm{H}_{2} \mathrm{SO}_{4}$ (p.a, merck®), kertas saring, dan akua DM.

Alat-alat yang akan digunakan meliputi labu ukur $25 \mathrm{~mL}$, labu ukur $50 \mathrm{~mL}$, labu ukur 100 $\mathrm{mL}$, labu ukur $250 \mathrm{~mL}$, corong, gelas kimia 100 $\mathrm{mL}$, gelas kimia $1000 \mathrm{~mL}$, pengaduk magnet, spatula, kaca arloji, batang pengaduk, lumpang alu, oven, loyang, desikator, dan ayakan ukuran 100 mesh $(149 \mu \mathrm{m})$.

\section{Instrumentasi}

Pengujian struktur kristal digunakan $X$-Ray Difraction (XRD) PAnalytical, pengujian komposisi adsorben digunakan X-Ray Fluorescence (XRF) merk Thermo ARL tipe ARL 9900, pengujian gugus fungsi penyusun digunakan Fourier Transform Infra Red (FTIR) merk agilent tipe FTIR-660, pengujian permukaan adsorben digunakan Scanning Electron Microscopy (SEM), dan pengujian kadar $\mathrm{Cu}$ digunakan Atomic Adsorption Spectrofotometer (AAS) merk agilent tope $240 \mathrm{FS}+\mathrm{VGA} 77$.

\section{Prosedur}

\section{Preparasi Sampel}

Sampel tulang ikan Gurame yang digunakan merupakan tulang yang belum melalui proses pemasakan karena sampel diambil dari limbah fillet ikan dan hanya bagian tulang rangka yang dijadikan sampel. Sampel tulang ikan Gurame direndam dalam air panas, dibersihkan dari daging yang masih menempel dan dicuci dengan akuades panas untuk menghilangkan residu yang masih menempel pada tulang. Selanjutnya tulang dikeringkan dalam oven dengan suhu $120^{\circ} \mathrm{C}$ dan didinginkan dalam desikator. Tulang yang telah dingin ditumbuk dan diayak dengan ukuran 100 mesh $(149 \mu \mathrm{m})$. Serbuk tulang ikan direndam dalam $\mathrm{NaOH} 0,1 \mathrm{M}$ dengan perbandingan (adsorben: $\mathrm{NaOH}$ 1:50 w/v) dan diaduk dengan pengaduk magnet dengan kecepatan $350 \mathrm{rpm}$ dengan suhu $60^{\circ} \mathrm{C}$ selama 2 jam. Adsorben selanjutnya disaring, dikeringkan dalam oven dengan suhu $80^{\circ} \mathrm{C}$ selama 24 jam dan didinginkan dalam desikator, selanjutnya adsorben yang sudah siap digunakan disimpan dalam wadah kedap udara.

\section{Karakterisasi Adsorben}

\section{Karakterisasi sebelum adsorpsi}

Karakterisasi adsorben dilakukan dengan menggunakan empat instrument, yaitu: XRD untuk mengidentifikasi struktur kristal pada adsorben, XRF untuk mengetahui persen koposisi adsorben, FTIR untuk mengetahui gugus fungsi penyusun adsorben dan SEM untuk mengetahui morfologi permukaan adsorben.

\section{Karakterisasi Setelah Adsorpsi}

Karakterisasi adsorben pada tahap ini dilakukan dengan instrumen FTIR untuk mengetahui pergeseran gugus fungsi setelah Adsorpsi.

\section{Penentuan Kondisi Optimum Adsorpsi}

\section{Pengaruh Optimasi Konsentrasi Larutan $\mathrm{CuSO}_{4}$}

Sebnayak 0,2 g adsorben dimasukkan ke dalam gelas kimia $100 \mathrm{~mL}$. masing-masing adsorben ditambahkan $20 \mathrm{~mL}$ larutan $\mathrm{CuSO}_{4}$ dengan berbagai konsentrasi, yaitu $10 \mathrm{mg} / \mathrm{L}, 20$ $\mathrm{mg} / \mathrm{L}, 30 \mathrm{mg} / \mathrm{L}, 40 \mathrm{mg} / \mathrm{L}$, dan $50 \mathrm{mg} / \mathrm{L}$. Campuran tersebut diaduk dengan menggunakan pengaduk magnet selama 15 menit. Selanjutnya campuran disaring dan filtratnya dianalisis dengan AAS untuk mengetahui seberapa besar penyerapan ion logam $\mathrm{Cu}(\mathrm{II})$ oleh adsorben dengan cara menentukan kadar $\mathrm{Cu}(\mathrm{II})$ yang tersisa pada larutan.

\section{Pengaruh Optimasi pH Adsorpsi}

Sebanyak 0,2 g adsorben dimasukkan ke dalam gelas kimia $100 \mathrm{~mL}$ dan ditambahkan 20 $\mathrm{mL}$ larutan $\mathrm{CuSO}_{4}$ dengan konsentrasi yang telah optimum, masing-masing campuran dikondisikan pHnya pada $\mathrm{pH} 4,5,6,7$, dan 8. Campuran diaduk dengan menggunakan pengaduk magnet selama 15 menit. 
Pengaruh optimasi waktu kontak adsorpsi

Sebanyak $0,2 \mathrm{~g}$ adsorben dimasukkan ke dalam gelas kimia $100 \mathrm{~mL}$, ditambahkan $20 \mathrm{~mL}$ larutan $\mathrm{CuSO}_{4}$ dengan konsentrasi yang telah optimum dan dikondisikan pada $\mathrm{pH}$ optimum. Selanjutnya masing-masing campuran diaduk dengan menggunakan pengaduk magnet selama 15 menit, 30 menit, 45 menit, 60 menit, dan 75 menit. Campuran disaring dan filtratnya dianalisis dengan AAS untuk mengetahui seberapa besar penyerapan ion logam $\mathrm{Cu}$ (II) oleh adsorben.

\section{Pengaruh Optimasi Massa Adsorben}

Adsorben divariasikan massanya yaitu masing-masing ditimbang sebanyak $0,1 \mathrm{~g} ; 0,2 \mathrm{~g}$; $0,3 \mathrm{~g} ; 0,4 \mathrm{~g}$; dan $0,5 \mathrm{~g}$ dan dimasukkan ke dalam gelas kimia $100 \mathrm{~mL}$. masing-masing adsorben ditambahkan $20 \mathrm{~mL}$ larutan $\mathrm{CuSO}_{4}$ dengan konsentrasi optimum dan dikondisikan pada $\mathrm{pH}$ optimum. Selanjutny masing-masing campuran diaduk dengan menggunakan pengaduk magnet dengan waktu kontak optimum. Campuran tersebut selanjutnya disaring dan filtratnya dianalisis dengan AAS untuk mengetahui seberapa besar penyerapan ion logam $\mathrm{Cu}(\mathrm{II})$ oleh adsorben.

\section{HASIL DAN PEMBAHASAN}

\section{Preparasi sampel}

Tulang ikan Gurame direndam dalam air panas agar lebih mudah untuk membersihkan sisa daging yang menempel pada tulang. Selanjutnya tulang dicuci dengan detergen sampai bersih, tulang kemudian dikeringkan dalam oven dengan suhu $120^{\circ} \mathrm{C}$ selama 2 jam agar tulang kering dan berdasarkan perhitungan terhitung kadar air pada tulang ikan Gurame setelah dikeringkan menjadi $2 \%$. Tulang yang telah kering dihaluskan dan diayak dengan ukuran $149 \mu \mathrm{m}$ untuk memperbesar luas permukaannya. Ukuran partikel sangat berpengaruh terhadap proses adsorpsi sehingga serbuk tulang yang halus lebih efektif untuk dijadikan adsorben karena apabila ukuran partikel diperkecil maka permukaan adsorben menjadi lebih luas sehingga lebih banyak permukaan adsorben yang siap untuk berinterasi dengan aktivator maupun dengan adsorbat dan proses penyerapan $\mathrm{Cu}(\mathrm{II})$ akan lebih optimal.

Serbuk tulang ikan Gurame dengan ukuran $149 \mu \mathrm{m}$ dilanjutkan ke proses aktivasi dengan aktivator. Fungsi dari aktivator adalah untuk membuka pori-pori adsorben dan melepas matriks yang menyumbat pori-pori adsorben sehingga proses adsorpsi berlangsung lebih optimal. Aktivator yang digunakan dalam penelitian ini adalah aktivator basa yaitu $\mathrm{NaOH} \quad 0,1 \mathrm{M}$. Pemilihan aktivator basa $\mathrm{NaOH}$ mengacu pada penelitian yang telah dilakukan oleh Han Kim Lim $d k k$ (2012) karena $\mathrm{NaOH}$ dapat membuka poripori adsorben tulang ikan dengan cara mengikat protein dan lemak yang terdapat pada tulang ikan sehingga kandungan senyawa organik pada tulang ikan Gurame berkurang [3].

Protein merupakan molekul besar dengan bobot molekul bervariasi antara 5000 sampai jutaan yang merupakan polimer dari asam amino yang dihubungkan oleh ikatan peptida. Pada umumnya asam amino dapat larut dalam air dan tidak larut dalam pelarut organik non polar. Dalam suasana basa ion $\mathrm{H}^{+}$pada gugus $\mathrm{NH}_{4}{ }^{+}$asam amino akan diikat oleh $\mathrm{OH}^{-}$. Selain itu lemak pada tulang ikan Gurame mengalami hidrolisis pada saat proses aktivasi dengan $\mathrm{NaOH}$ membentuk gliserol dan sabun (safonifikasi) sehingga kadar lemak pada tulang ikan Gurame berkurang.

\section{Karakterisasi adsorben}

\section{Karakterisasi XRD}

Adsoben yang dianalisis dengan XRD merupakan serbuk tulang ikan Gurame yang belum digunakan untuk adsorpsi, sehingga diketahui komponen penyusun dari tulang ikan dan struktur kristalnya.

Hasil dari analisis XRD menunjukkan terbentuknya hidroksiapatit dengan struktur heksagonal karena terdapat kesamaan nilai $2 \theta$ antara tulang ikan Gurame dengan database referensi hidroksiapatit heksagonal dengan kode 01-089-6440 yaitu pada $2 \theta 10,833 ; 22,854$; 25,$867 ; 31,765 ; 38,171 ; 46,687 ; 53,184 ; 60,407$; dan 64,151 akan tetapi dengan kristalinitas yang rendah karena memiliki puncak karakteristik yang lebar seperti yang terlihat pada Gambar 1.

Selain itu, dalam sampel tulang ikan Gurame diketahui terdapat pula kalsium dalam bentuk senyawa yaitu kalsium karbonat. Adanya kalsium karbonat pada sampel dikarenakan terdapat beberapa kesamaan puncak adsorben tulang ikan gurami dengan standar kalsium karbonat dengan kode 96-900-7287 dimana berdasarkan perhitungan match diketahui terdapat hidroksiapatit dengan persentase $95,6 \%$ dan kalsium karbonat 4,4\%. 


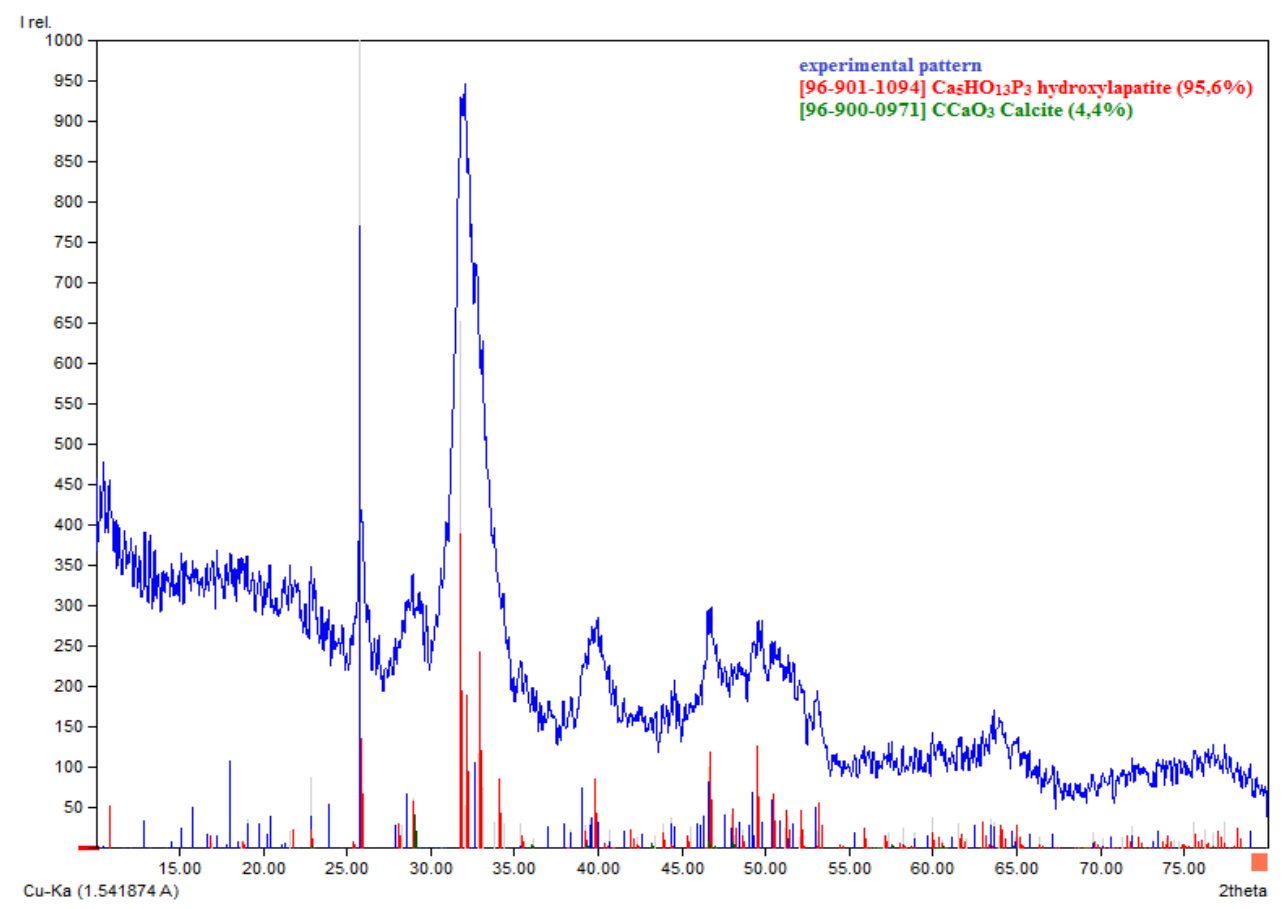

Gambar 1. Difraktogram tulang ikan Gurame

\section{Karakterisasi XRF}

Adsorben yang dianalisis dengan XRF merupakan serbuk tulang ikan Gurame yang belum digunakan untuk adsorpsi. Komposisi adsorben tulang ikan Gurame ditunjukkan pada Tabel 1. Dari hasil analisis XRF diketahui bahwa mineral yang ada pada adsorben tulang ikan Gurame adalah Si, Ti, Al, Fe, Mn, Ca, Mg, Na, K, $\mathrm{P}$, dan S. Kalsium dan fosfor memiliki persentase yang paling besar dalam adsorben yaitu masingmasing sebesar $27,56 \%$ dan $10,81 \%$ karena unsur utama penyusun tulang adalah kalsium dan fosfat.

Tabel 1. Hasil analisis XRF

\begin{tabular}{cc}
\hline Unsur & Massa $(\%)$ \\
\hline $\mathrm{Si}$ & 0,8090 \\
$\mathrm{Ti}$ & 0,0035 \\
$\mathrm{Al}$ & 0,0340 \\
$\mathrm{Fe}$ & 0,0138 \\
$\mathrm{Mn}$ & 0,0070 \\
$\mathrm{Ca}$ & 27,5600 \\
$\mathrm{Mg}$ & 0,4830 \\
$\mathrm{Na}$ & 0,3480 \\
$\mathrm{~K}$ & 0,0192 \\
$\mathrm{P}$ & 10,8100 \\
$\mathrm{~S}$ & 0,0494 \\
$\mathrm{LOI}$ & 34,9200 \\
\hline
\end{tabular}

Sedangkan berdasarkan perhitungan dengan aplikasi match terhitung \%Ca pada adsorben sebesar 39,90\% dan \%P sebesar 17,68\%, hasil tersebut mendekati dengan nilai \% Ca dan $\mathrm{P}$ berdasarkan hasil XRF apabila kita mengabaikan nilai LOI dan beranggapan bahwa komponen penyusun adsorben hanyalah hidroksiapatit dan kalsit yaitu \%Ca sebesar $42,34 \%$ dan \%P sebesar $16,61 \%$. Rasio mol $\mathrm{Ca} / \mathrm{P}$ hidroksiapatit pada tulang ikan Gurame yaitu 1,97 menunjukkan hasil yang lebih tinggi dari perbandingan $\mathrm{Ca} / \mathrm{P}$ hidroksiapatit komersial yaitu sebesar 1,67 yang disebabkan oleh dominasi $\mathrm{Ca}$ (II) dalam sampel adsorben hal tersebut disebabkan oleh karena dalam adsorben tidak hanya terdapat $\mathrm{Ca}(\mathrm{II})$ dalam bentuk kalsium hidroksiapatit, akan tetapi terdapat pula $\mathrm{Ca}(\mathrm{II})$ dalam bentuk senyawa lain seperti $\mathrm{CaCO}_{3}$ seperti yang terlihat pada hasil karakterisasi XRD dan adanya puncak $\mathrm{CO}_{3}{ }^{2-}$ pada hasil FTIR pada panjang gelombang 1.553,245 $\mathrm{cm}-1$ dan nilai LOI yang tinggi yaitu mencapai $34,92 \%$ yang disebabkan oleh adanya $\mathrm{CaCO}_{3}$ dan senyawa organik lainnya. Adanya unsur lain selain penyusun hidroksiapatit seperti $\mathrm{Mg}, \mathrm{Na}, \mathrm{K}$ dll karena komposisi mineral pada tulang tidak hanya Ca dan P melainkan ada mineral-mineral lain akan tetapi dengan persentase yang sangat kecil.

\section{Karakterisasi FTIR}

Analisis FTIR bertujuan untuk menentukan gugus fungsi yang ada pada adsorben tulang ikan Gurame, sampel yang dianalisis FTIR adalah tulang ikan Gurame sebelum dan setelah adsorpsi sehingga dapat diketahui perubahan spektrum yang disebabkan oleh proses adsorpsi. 


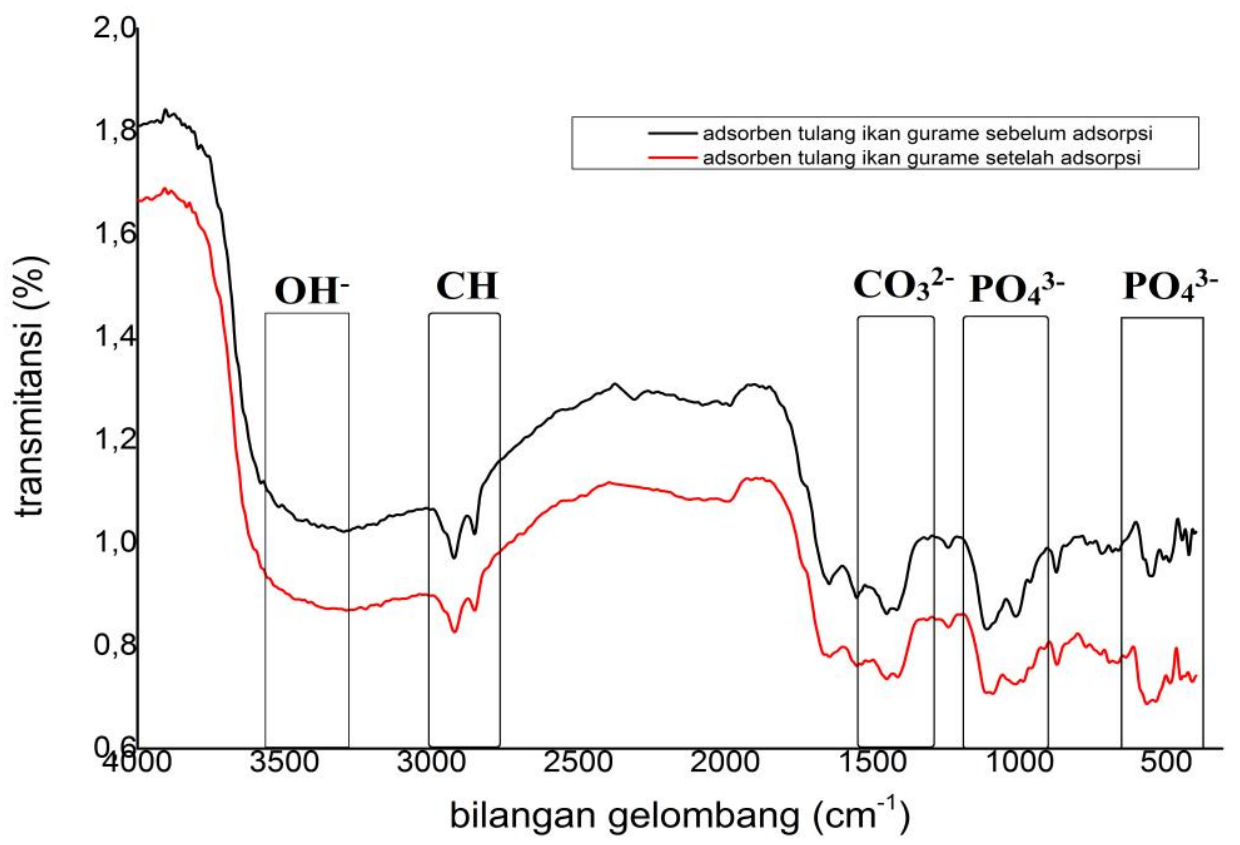

Gambar 2. Hasil FTIR tulang ikan Gurame sebelum dan setelah adsorpsi

Kemampuan adsorpsi tulang ikan Gurame terhadap logam $\mathrm{Cu}(\mathrm{II})$ dipengaruhi oleh gugus aktif penyusun tulang tersebut. Berdasarkan hasi analisis FTIR diketahui gugus aktif penyusun adsorben tulang ikan Gurame adalah $\mathrm{OH}^{-}$dan $\mathrm{PO}_{4}{ }^{3-}$ yang merupakan penyusun Kristal kalsium hidroksiapatit $\left[\mathrm{Ca}_{10}\left(\mathrm{PO}_{4}\right)_{3}(\mathrm{OH})_{2}\right]$ seperti terlihat pada Gambar 2.

Kemampuan dalam proses adsorpsi ini dipengaruhi oleh adanya gugus aktif pada adsorben. Dilihat dari spektrum pada Gambar 2. Adanya gugus $\mathrm{PO}_{4}{ }^{3-}$ teridentifikasi pada spektra dengan bilangan gelombang 553-600 dan 1000$1100 \mathrm{~cm}^{-1}$, sedangkan adanya gugus $\mathrm{OH}^{-}$ teridentifikasi pada spektrtrum dengan panjang gelombang 2.500-3.000 dan $3.568 \mathrm{~cm}^{-1}$. Dari hasil analisa terlihat pergeseran puncak gugus fosfat yang semula pada bilangan gelombang 548,468 $\mathrm{cm}^{-1}$ bergeser menjadi $566,716 \mathrm{~cm}^{-1}$ dan 1012,894 $\mathrm{cm}^{-1}$ bergeser menjadi 1013,162 $\mathrm{cm}^{-1}$ pada adsorben yang telah digunakan untuk adsorpsi. Terjadinya pergeseran gugus tersebut karena terjadinya proses penyerapan $\mathrm{Cu}$ (II) oleh adsorben yang menggantikan $\mathrm{Ca}$ (II) yang terikat oleh gugus fosfat [4].

\section{Karakterisasi SEM}

SEM dilakukan untuk analisis morfologi permukaan dari adsorben tulang ikan Gurame. SEM bekerja berdasarkan prinsip scan sinar elektron pada permukaan sampel, selanjutnya informasi yang diperoleh diubah menjadi gambar [5]. Pada SEM gambar dibuat berdasarkan deteksi elektron baru (elektron sekunder) atau elektron pantul yang muncul dari permukaan sampel ketika permukaan sampel tersebut discan dengan sinar elektron [5].

Hasil karakterisasi SEM perbesaran 2.000x pada Gambar 3 tampak partikel penyusun hidroksiapatit memiliki bentuk yang tidak seragam. Ukuran partikel hidroksiapatit dari tulang ikan Gurame tampak sangat besar dengan bentuk bulat memanjang karena hidroksiapatit mengalami aglomerasi (penggumpalan) yang disebabkan oleh pembentukkan kristal tidak sempurna. Selain itu susunan dan jarak antar partikelnya pun tidak teratur, hal tersebut dikarenakan tulang ikan secara umum mengandung hidroksiapatit dengan tingkat kristalinitas yang sangat rendah. Berdasarkan hasil foto SEM terlihat jika hidroksiapatit merupakan mikropartikel yang memiliki rongga-rongga antar partikelnya [6].

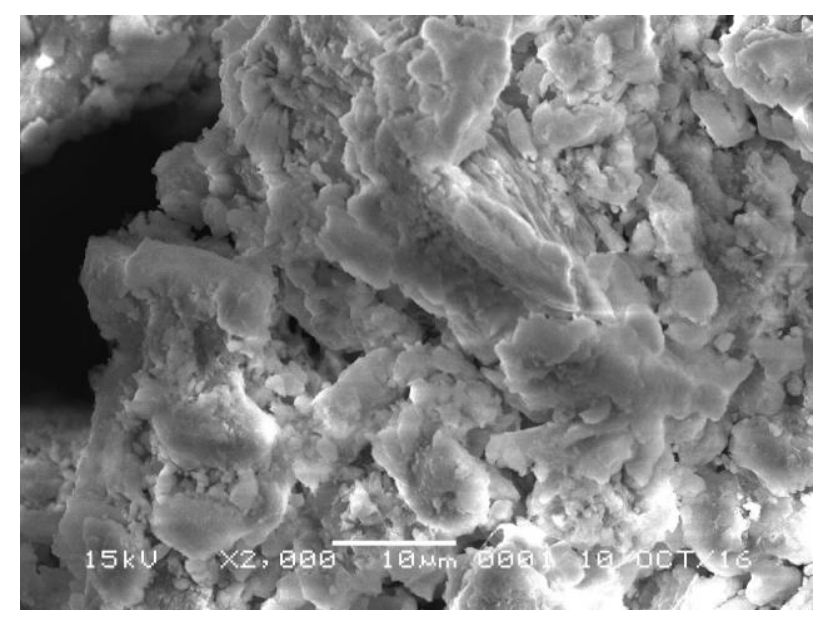

Gambar 3. Hasil SEM adsorben tulang ikan Gurame 


\section{Penentuan Kondisi Optimum Adsorpsi}

\section{Pengaruh Optimasi Konsentrasi Larutan $\mathrm{CuSO}_{4}$}

Optimasi konsentrasi dilakukan untuk mengetahui konsentrasi $\mathrm{Cu}(\mathrm{II})$ optimum yang dapat diserap oleh adsorben tulang ikan Gurame. Berdasarkan Gambar 4 efisiensi adsorpsi meningkat seiring meningkatnya konsentrasi $\mathrm{Cu}$ (II) karena semakin banyak ion $\mathrm{Cu}$ (II) dalam larutan maka semakin banyak pula $\mathrm{Cu}(\mathrm{II})$ yang akan diserap oleh adsorben. Pada larutan $\mathrm{Cu}$ (II) konsentrasi $10 \mathrm{mg} / \mathrm{L}$ efisiensi adsorpsinya 81,65\% dan efisiensi terus meningkat pada konsentrasi 20, 30 dan $40 \mathrm{mg} / \mathrm{L}$ karena hidroksiapatit pada tulang ikan Gurame belum jenuh dan masih dapat menyerap $\mathrm{Cu}(\mathrm{II})$ pada larutan sampai pada efisiensi 90,0\% pada konsentrasi $\mathrm{Cu}(\mathrm{II}) 40 \mathrm{mg} / \mathrm{L}$.

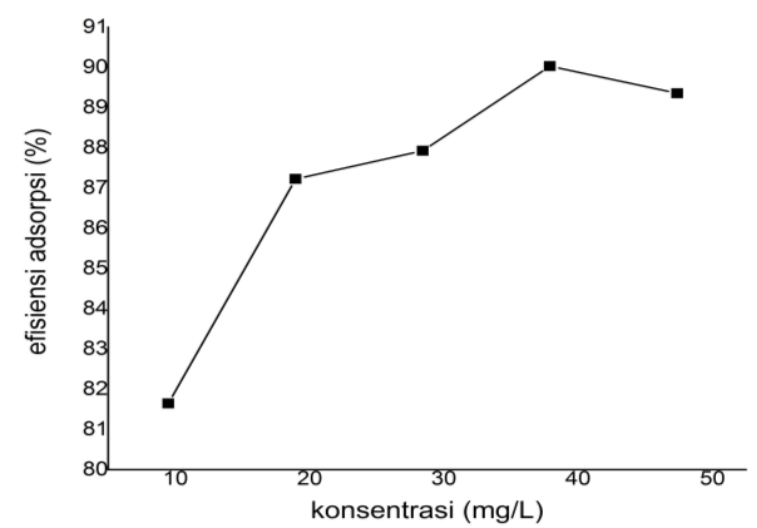

Gambar 4. Kurva efisiensi adsorpsi optimasi konsentrasi $\mathrm{Cu}(\mathrm{II})$

Pada larutan $\mathrm{Cu}$ (II) konsentrasi $50 \mathrm{mg} / \mathrm{L}$ terjadi penurunan efisiensi adsorpsi menjadi $89,35 \%$ karena jumlah ion $\mathrm{Ca}(\mathrm{II})$ pada hidroksiapatit telah berkurang dan hampir seluruhnya bertukar dengan $\mathrm{Cu}$ (II) dalam larutan dan hidroksiapatit sudah jenuh sehingga sudah tidak dapat menyerap $\mathrm{Cu}(\mathrm{II})$ dan menyebabkan penurunan efisiensi adsorpsi. Dari data tersebut diperoleh efisiensi adsorpsi $\mathrm{Cu}$ (II) optimum pada konsentrasi $\mathrm{CuSO}_{4} 40 \mathrm{mg} / \mathrm{L}$.

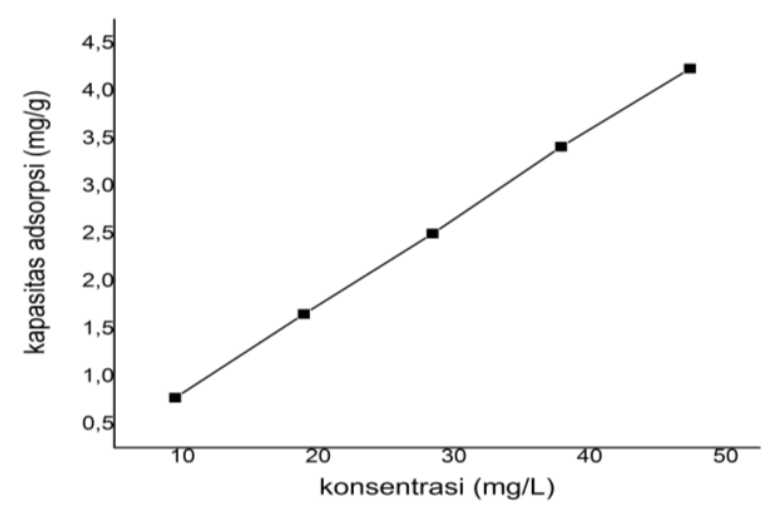

Gambar 5. Kurva kapasitas adsorpsi optimasi konsentrasi $\mathrm{Cu}(\mathrm{II})$
Hasil AAS optimasi konsentrasi pada Gambar 5 menunjukkan bahwa data kapasitas adsorpsi yang terus meningkat seiring meningkatnya konsentrasi. Semakin besar konsentrasi $\mathrm{Cu}$ (II) dalam air maka semakin besar pula kapasitas penyerapan $\mathrm{Cu}$ (II) oleh adsorben.

\section{Pengaruh Optimasi pH Adsorpsi}

Salah satu faktor yang dapat mempengaruhi efektifitas adsorpsi adalah $\mathrm{pH}$. Sedikit banyaknya jumlah $\mathrm{Ca}$ (II) yang dipertukarkan dengan $\mathrm{Cu}$ (II) bergantung pada $\mathrm{pH}$ keadaan adsorpsi. Hidroksiapatit akan mulai terdemineralisasi pada $\mathrm{pH}$ dibawah 5,5 yang menyebabkan terlepasnya $\mathrm{Ca}$ (II) pada apatit sehingga terjadi kekosongan pada gugus fosfat. Kekosongan pada gugus fosfat tersebut yang menyebabkan terserapnya $\mathrm{Cu}$ (II) oleh adsorben, sehingga pada $\mathrm{pH}$ asam efisiensi penyerapan $\mathrm{Cu}$ (II) sangat baik. Pada $\mathrm{pH}$ basa $\mathrm{Ca}(\mathrm{II})$ pada apatit sulit untuk lepas sehingga interaksi $\mathrm{Cu}$ (II) dengan adsorben kurang baik dan efisiensi adsorpsinya merurun. Dari penelitian ini didapatkan hasil efisiensi adsorpsi terbesar adalah pada $\mathrm{pH} 4$ yaitu mencapai 90,16\% seperti yang terlihat pada Gambar 6.

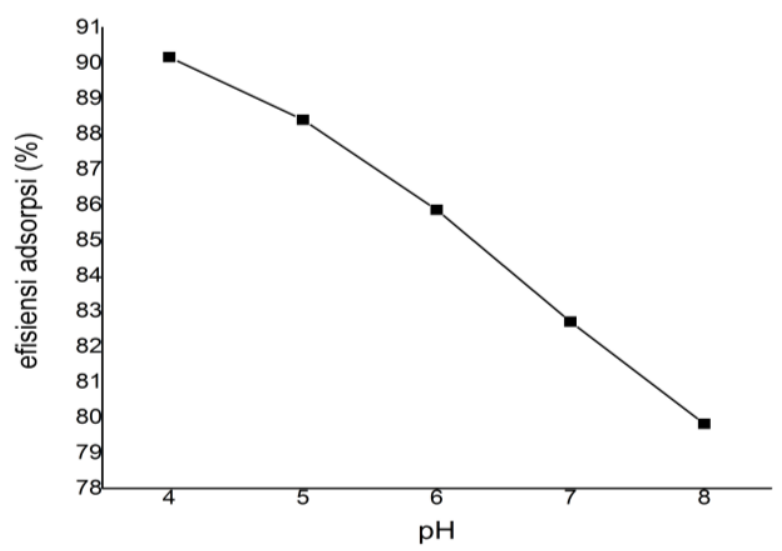

Gambar 6. Kurva efisiensi adsorpsi optimasi pH

Hasil penelitian menunjukan nilai kapasitas adsorpsi berbanding lurus dengan nilai efisiensi adsorpsi artinya pada $\mathrm{pH} 4$ penyerapan $\mathrm{Cu}(\mathrm{II})$ oleh adsorben sangat baik karena memiliki nilai efisiensi tertinggi dan mampu menyerap $3,7 \mathrm{mg}$ $\mathrm{Cu}$ (II) per gram adsorbennya.

Semakin tinggi $\mathrm{pH}$ pada proses adsorpsi nilai kapasitas adsorpsi semakin kecil karena pada $\mathrm{pH}$ diatas 5,5 $\mathrm{Ca}$ (II) pada adsorben sulit untuk dilepaskan sehingga apabila $\mathrm{Ca}$ (II) sulit dilepaskan oleh adsorben maka $\mathrm{Cu}(\mathrm{II})$ pada larutan sulit untuk diserap oleh adsorben karena proses adsorpsi oleh hidroksiapatit merupakan sistem pertukaran ion seperti yang terlihat pada Gambar 7. 


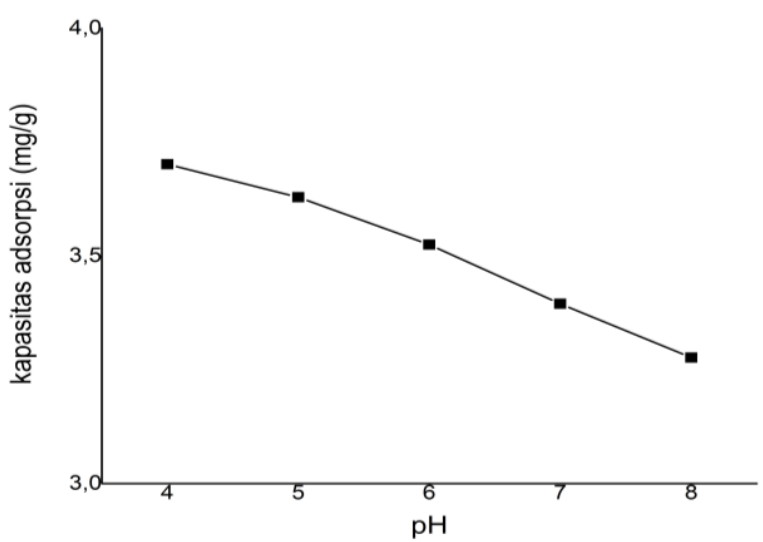

Gambar 7. Kurva kapasitas adsorpsi optimasi pH

\section{Optimasi Waktu Kontak Adsorpsi}

Fungsi optimasi waktu kontak adalah untuk mengetahui waktu interaksi adsorben dan adsorbat yang optimum. Pada waktu kontak 15 menit efisiensi penyerapan $\mathrm{Cu}(\mathrm{II})$ oleh adsorben sebesar $84,89 \%$ dan terus meningkat sampai waktu kontak 45 menit dengan efisiensi adsorpsi 89,15\%.

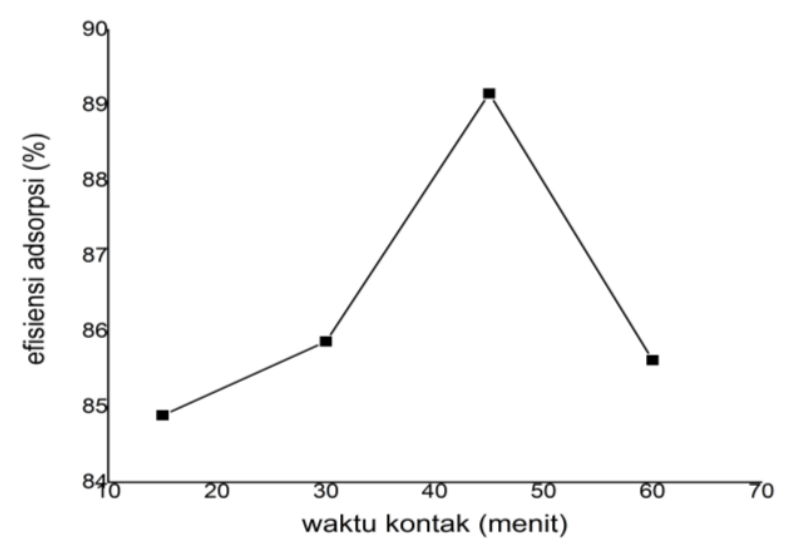

Gambar 8. Kurva efisiensi adsorpsi optimasi waktu kontak

Berdasarkan Gambar 8 terlihat bahwa semakin lama waktu adsorpsi maka waktu interaksi $\mathrm{Cu}(\mathrm{II})$ dengan adsorben semakin lama sehingga penyerapan $\mathrm{Cu}$ (II) oleh adsorben akan semakin besar. Pada waktu kontak 60 menit terjadi penurunan efisiensi adsorpsi menjadi $85,62 \%$ karena pada waktu yang terlalu lama ion $\mathrm{Cu}$ (II) pada adsorben akan jenuh sehingga terjadi proses desorpsi atau pelepasan kembali ion $\mathrm{Cu}$ (II) yang telah diserap oleh adsorben sehingga $\mathrm{Cu}$ (II) terlepas kembali membentuk $\mathrm{Cu}$ bebas dalam larutan.

Kurva hubungan antara waktu kontak dengan kapasitas adsorpsi memiliki pola yang sama dengan kurva efisiensi adsorpsi optimasi waktu kontak. Pada waktu kontak 15 menit kapasitas adsorpsi $\mathrm{Cu}(\mathrm{II})$ bernilai kecil yaitu 3,4 $\mathrm{mg} / \mathrm{g}$ dan terus meningkat hingga waktu kontak 45 menit. Kapasitas adsorpsi optimum adalah pada waktu kontak 45 menit yaitu mencapai $3,5 \mathrm{mg} / \mathrm{g}$ artinya pada waktu kontak 45 menit adsorben dapat menyerap $\mathrm{Cu}$ (II) pada larutan hingga $3,5 \mathrm{mg}$ per gram asorbennya. Hal ini dapat dilihat pada Gambar 9.

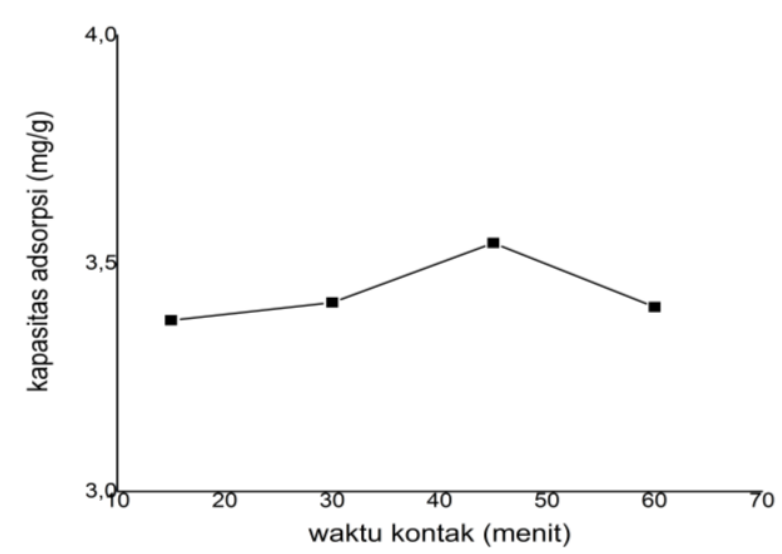

Gambar 9. Kurva kapasitas adsorpsi optimasi waktu kontak

\section{Optimasi Massa Adsorben}

Berdasarkan teori semakin banyak masa adsorben yang digunakan maka akan semakin banyak pula $\mathrm{Ca}$ (II) pada struktur hidroksiapatit adsorben yang dapat dipertukarkan dengan $\mathrm{Cu}$ (II) dalam larutan sehingga akan lebih banyak $\mathrm{Cu}(\mathrm{II})$ yang terserap adsorben. Efisiensi akan meningkat seiring dengan meningkatnya massa adsorben.

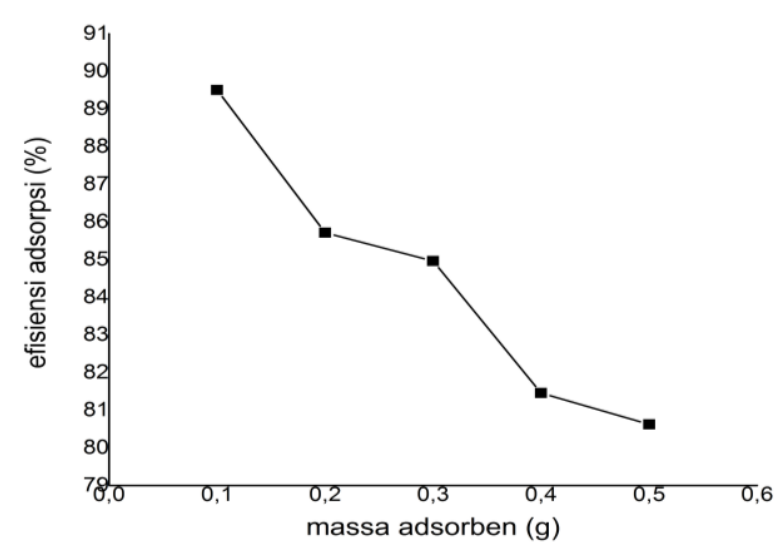

Gambar 10. Kurva efisiensi adsorpsi optimasi massa adsorben

Hasil analisa didapatkan data yang tidak sesuai dengan teori yaitu efisiensi adsorpsi terbesar pada massa adsorben $0,1 \mathrm{~g}$ dan efisiensi terkecil pada massa adsorben $0,5 \mathrm{~g}$ yang terlihat pada Gambar 10. Hal tersebut dapat disebabkan oleh karena masih adanya protein ataupun lemak yang tidak terhidrolisis sempurna pada tulang ikan Gurame.

Hasil optimasi massa adsorben pada Gambar 11 didapatkan penurunan kapasitas adsorpsi seiring dengan meningkatnya jumlah 
adsorben yang digunakan. Penurunan kapasitas adsorpsi ini disebabkan oleh semakin banyak adsorben yang digunakan dengan konsentrasi larutan $\mathrm{Cu}$ (II) yang sama maka jumlah mg $\mathrm{Cu}(\mathrm{II})$ yang terserap per gram adsorben akan semakin kecil.

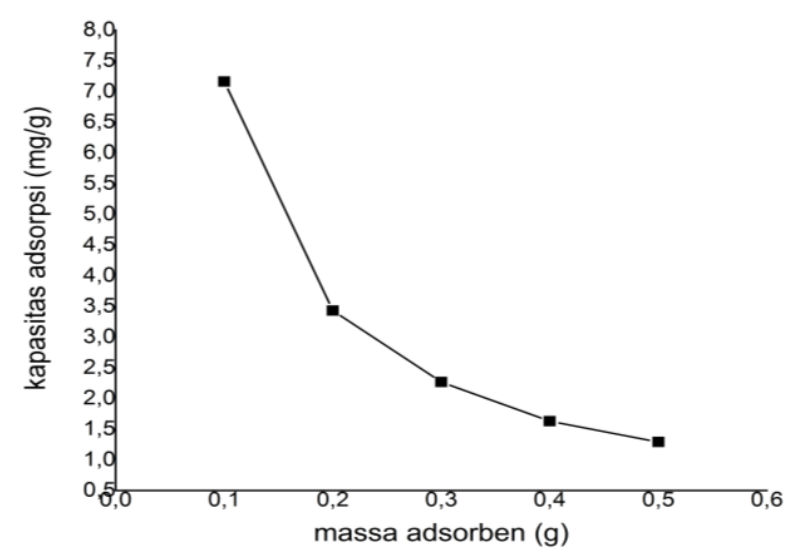

Gambar 11. Kurva kapasitas adsorpsi optimasi massa adsorben

Berdasarkan hasil penelitian didapatkan nilai efisiensi penyerapan $\mathrm{Cu}(\mathrm{II})$ oleh adsorben sebesar $89 \%$ dengan kapasitas adsorpsi mencapai $7,2 \mathrm{mg} / \mathrm{g}$.

\section{SIMPULAN}

Penelitian ini dapat ditarik kesimpulan sebagai berikut:

1. Hasil karakterisasi adsorben oleh XRD, XRF, SEM, dan FTIR menunjukkan adanya $\mathrm{Ca}_{10}\left(\mathrm{PO}_{4}\right)_{6} \mathrm{OH}_{2}$ pada adsorben dengan ukuran mikro dengan rasio $\mathrm{Ca} / \mathrm{P}$ sebesar 1,97.

2. Keadaan optimum penyerapan $\mathrm{Cu}(\mathrm{II})$ oleh adsorben tulang ikan adalah pada konsentrasi $\mathrm{CuSO}_{4} 40 \mathrm{mg} / \mathrm{L}, \mathrm{pH} 4$, dan waktu kontak 45 menit. Akan tetapi tidak didapatkan massa adsorben yang optimum.

3. Serbuk tulang ikan Gurame efektif untuk dijadikan adsorben logam $\mathrm{Cu}(\mathrm{II})$ karena memiliki kapasitas adsorpsi sebesar 7,2 mg/g dengan efisiensi adsorpsi sebesar $89 \%$.

\section{UCAPAN TERIMA KASIH}

Penulis mengucapkan terima kasih kepada Laboratorium Instrumen Kimia FST UIN SGD Bandung atas diskusi interpretasi Fourier Transform Infra Red (FTIR) dan analisis Atomic Absorption Spectroscopy (AAS); Laboratorium Pusat Survei Geologi (PSG) atas diskusi metode X-Ray Fluorescence (XRF) dan Scanning Electron Microscopy (SEM).

\section{REFERENSI}

[1] N. Priyanto, D. dan F. Ariyani, "Kandungan Logam Berat $(\mathrm{Hg}, \mathrm{Pb}, \mathrm{Cd}$, dan $\mathrm{Cu})$ pada Ikan, Air dan Sedimen di Waduk Cirata, Jawa Barat," Jurnal Pascapanen dan Bioteknologi Kelautan dan Perikanan, vol. 3, Juni 2008.

[2] H. Analisis Fisika Kimia, Jakarta: Departemen Farmasi FMIPA-UI, 2006.

[3] K. L. Han, T. T. Tjoon dan H. I. Muhamad, "Adsorption and Removal of Zinc (II) from Aqueous Solution Using Powdered Fish Bones," Elsevier, vol. I, pp. 96-102, January 2012.

[4] A. A. dan Z. , "Sintesis Hidroksiapatit dari Cangkang Kerang Darah (Anadara granosa) dengan Proses Hidrotermal Variasi Rasio Mol $\mathrm{Ca} / \mathrm{P}$ dan Suhu Sintesis," Jom FTEKNIK, vol. 2, no. 1, Februari 2015.

[5] B. S. Purwasasmita dan R. S. Gultom, "Sintesis dan Karakterisasi Serbuk Hidroksiapatit Skala Sub-Mikron Menggunakan Metode Presipitasi," Jurnal Bionatura, vol. 10, no. 2, pp. 155-167, Juli 2008.

[6] B. Riyanto, A. Maddu dan N. , "Material Biokeramik Berbasis Hidroksiapatit Tulang Ikan Tuna," JPHPI, vol. 16, no. 2, November 2013. 